Jurnal Keislaman, Vol. 2, No. 1, Maret

\title{
HAM (HAK ASASI MANUSIA) DALAM ISLAM
}

\author{
Oleh : Zuman Malaka ${ }^{1}$ \\ e-mail : zuman_mlk@yahoo.co.id
}

STAI TARUNA Surabaya

\begin{abstract}
ABSTRAK : Sebenarnya masalah hak asasi manusia bukanlah merupakan masalah baru bagi masyarakat dunia, karena isu hak asasi manusia sudah mulai dilontarkan sejak lahirnya Magna Charta di Inggris pada tahun 1215, sampai lahirnya Piagam Perserikatan Bangsa-Bangsa tentang Hak Asasi Manusia, yaitu Universal Declaration Of Human Right pada tanggal 10 Desember 1948, tetapi ternyata jauh sebelum lahir Magna Charta di Inggris tahun 1215, sebenarnya di dunia Islam telah terbit dahulu ada suatu piagam tentang hak azasi manusia yang dikenal dengan Piagam Madinahdi Madinah pada tahun 622, yang memberikan jaminan perlindungan hak azasi manusia bagi penduduk Madinah yang terdiri atas suku dan agama.

Sesudah perang dingin arus gelombang hak asasi manusia semakin melanda seantero dunia, malah kadang-kadang negara-negara barat terkesan ingin melaksanakan penerapan konsep hak asasi manusia menurut pandangan mereka terhadap negara-negara lain, tanpa memperhatikan keanekaragaman tata nilai, sejarah, kebudayaan, system, politik, tingkat pertumbuhan sosial dan ekonomi, serta faktor-faktor lain yang dimiliki bangsa yang bersangkutan.
\end{abstract}

\section{Kata kunci : HAM, Islam}

\section{A. PROLOG}

Sebenarnya masalah hak asasi manusia bukanlah merupakan masalah baru bagi masyarakat dunia, karena isu hak asasi manusia sudah mulai dilontarkan sejak lahirnya Magna Charta di Inggris pada tahun 1215, sampai lahirnya Piagam Perserikatan Bangsa-Bangsa tentang Hak Asasi Manusia, yaitu Universal Declaration Of Human Right pada tanggal 10 Desember $1948 .^{2}$

\footnotetext{
${ }^{1}$ Dosen Tetap STAI Taruna Surabaya

${ }^{2}$ Rozali Abdullah dan Syamsir, Perkembangan HAM dan Keberadaan Peradilan HAM di Indoenesia (Jakarta: Penerbit Ghalia ndonesia,2001) h. 9.

1
} 
Perjuangan untuk memperoleh pengakuan dan jaminan terhadap hak azasi manusia, sepanjang sejarah umat manusia selalu mengalami pasang surut. Puncak keberhasilan perjuangan untuk memperoleh pengakuan dan jaminan perlindunagan terhadap hak azasi manusia, ditandai dengann lahirnya Piagam Perserikatan Bangsa-Bangsa tentang Hak Azasi Manusia yang dikenal dengan "Universal Declaration of Human Right". Semenjak itu masalah hak azasi manusia betul-betul telah menjadi perhatian dunia, terlebih-lebih sesudah berakhirnya perang dingin, terutama di negara-negara maju. Meskipun demikian pelanggaran terhadap hak azasi manusia tetap saja terjadi tidak saja di negaranegara Berkembang, tetapi ironisnya di negara-negara maju seperti amerika serikat, yang menamakan dirinya pendekar hak azasi manusia.

Jauh sebelum lahir Magna Charta di Inggris tahun 1215, sebenarnya di dunia Islam telah terbit dahulu ada suatu piagam tentang hak azasi manusia yang dikenal dengan Piagam Madinahdi Madinah pada tahun 622, yang memberikan jaminan perlindungan hak azasi manusia bagi penduduk Madinah yang terdiri atas suku dan agama. ${ }^{3}$

Apabila kita berbicara tentang dunia islam, maka yang sering menjadi tolak ukur adalah pada hukum islamnya, karena selama ini dunia Islam identik dengan hukum Islam, sehingga sering sekali apabila suatu negara Islam yang berlaku dinilai melanggar hak azasi manusia, maka yang disalahkan adalah islamnya bukan kesalahan pada personal pemerintahan yang berkuasa pada saat itu dan ini tidak adil kalau kemudian Islam yang menjadi sasaran terhadap kesalahan-kesalahan tersebut.

Perlu kita ketahui bahwa Islam lahir diantara sistem kesukuaan arab yang kacau dan tidak terstruktur ditandai dengan tidak adanya satupun kekuasaan (centralizied authority) Sejak sebelum kelahiran Nabi Muhammad SAW.

${ }^{3}$ Ibid h. 10 
Salah satu fakta kuat dan mengikat seluruh pengikut Muhammad adalah factor keimanan (faith) yang mampu menyatukan mereka dalam suatu komunitas yang terorganisasi, Al Quran menyebutnya sebagai ummah dan menyebut pengikutnya sebagai mukmin (orang yang percaya) dan menyebut idiologinya sebagai islam atau penyerahan diri terhadap Tuhan Yang Maha Esa (Allah). ${ }^{4}$

Praktek politik negara islam yang ideal dan original sebagaimana diemban oleh Rosulullah secara gradual mengalami kemunduran terutama pasca wafatnya Nabi dan empat kholifah pertama. Sejarah negara islam selalu diliputi oleh konflik kekuasaan disatu sisi, dan syariah yang pada dasarnya merupakan instrumen progresif bagi perkembangan umat, telah kehilangan dinamisasinya dan berubah menjadi hukum (fuqoha), serta ketidakberdayaan para pemegang otoriter syariah atas dominasi kekuatan politik para penguasa disisi lain.

Dinasti Umayyah telah memerintah selama \pm 100 tahun (661-650) meletakkan pondasi bagi sebuah system politik baru yang belum dikenal ooleh bangsa Arab pada waktu itu. Mereka mengadopsi tata cara pengadilan Persia, Byzantium, dan memperbaruhi pemerintahan dan way of life mereka. ${ }^{5}$ Dalam priode inilah mulai terjadi penyimpangan yang sangat membahayakan ajaran islam. Melalui interprestasi yang lihai dibuat-buat terhadap beberapa ayat-ayat Al Quran.

Dinasti Abbasyiyyah tidaklah religius dan jujur dibandingkan pendahulunya, walaupun priode ini mendapatkan reputasi sebagai Masa Keemasan Islam (Golden Age of Islam). Tetapi selama priode ini, instituís kekholifahan kehilangan kejayaannya dan efisiensinya. Kondisi tersebut mendapatkan respon para Fuqohadan Teolog muslim, tetrapi pendekatan yang mereka gunakan masih juga bersifat tidak realistis dan jauh dari realitas sehingga tidak dapat memberikan solusi untuk mengatasi para pengusaha yang lalim dan

\footnotetext{
${ }^{4}$ Manovehert Paydar, Legitimasi Negara Islam (Yogyakarta: fajar Pustaka Baru, 2003) h. 11.

${ }^{5} \mathrm{lbid}$, h.106

3
} 
mengabaikan hukum islam. ${ }^{6}$ Dengan pengelolahan politik yang semacam itu, dibidang hukum mustahil untuk tidak terpengaruh. Pada kenyataannya syariah sejak awal menjadi target yang paling mudah diserang dalam pemerintahan islam.

Di negara-negara muslim, pada sisi lain sejak pondasi syariah prinsipprinsip religius yang tidak bisa dirubah dan keluar, para fuqoha mencoba untuk melindungi bangunan hukum Islam dari perubahan dan menjadikan taqlid sebagai sesuatu yang diterima secara universal.

Dalam syariat Islam ditegaskan bahwa diri kita juga memiliki hak-hak tertentu terhadap kita. Syariat melarang penggunaan segala sesuatu yang berbahaya bagi fisik, mental, atau moral manusia. Ia melarang manusia dari menkonsumsi darah, obat-obatan beracun, darah daging babi, binatang-binatang buas, dan binatang-binatang yang mengandung kotor dan bangkai, semuanya ini mempunyai pengaruhn yang tak diinginkan terhadap fisik, moral, intelektual, dan spiritual manusia. Sementara itu islam memerintahnkan pemakaian hal-hal yang bersih, sehat, dan bermanfaat bagi manusia, karena diri kita juga mempunyai hak atas kita.

Islam mengakui adanya keinginan seksual dan mengaturnya dengan mencari pemenuhannya lewat perkawinan. Juga dalam mencari peningkatan spiritual atau kemurnian moral, kita tidak disuruh meninggalkan kehidupan dunia. Jalan untuk sukses terletak dalam mengikuti hukum Tuhan ditengahtengah kompleksitas kehidupan dan bukan diluar itu. Islam juga secara total melarang bunuh diri kesemuanya ini menunjukkan pada manusia bahwa dirinya sendiri menikmati hak-hak tertentu dan menjadi kewajiban bagi manusia untuk memenuhinya sebaik mungkin, melalui jalan yang telah diarahkan oleh syariat. Pada suatu sisi syariat memerintahkan manusia untuk mengisi hak-hak pribadinya dan bertindak adil terhadap dirinya sendiri, dan pada sisi lain, ia juga

${ }^{6} \mathrm{Ibid}$, h.110 
menyuruh manusia untuk mencari pemenuhan itu dengan suatu jalan diman hakhak orang lain tidak dibahayakan.

Syariat mencoba untuk mencapai suatu keseimbangan diantara hak-hak seorang manusia dan hak-hak masyarakat sehingga tidak ada konflik antara keduanya dan semuanya harus bekerja sama dalam melaksanakan hukum tuhan. Seorang muslim didunia ini lahir untuk menjadi simbol hidup dari kebaikan, kemuliaan dan kemaniusiaan. Dia harus menenangkan hati-hati manusia melalui karakter dan contohnya. Kemudian dia sendiri dapat menjadi true ambassador of Islam ( duta besar sejati dari islam). ${ }^{7}$

Ada dua kelompok besar yang berbeda memegang pendapat bahwa system hukum Islam tidak selaras dengan perkembangan zaman. Pertama, mereka yang tidak punya pengetahuan baik hukum islam maupun hukum modern, sementara kelompok yang kedua mengenal hukum modern tetapi tidak tahu apa-apa tentang hukum Islam, dengan percatan lain, kedua kelompok tersebut tidak berkompeten untuk membuat suatu komentar terhadap kaum Islam, sebab mereka sama sekali tidak mengerti. Anda tidak dapat dengan jelasmenilai sesuatu yang anda tidak mengerti sama sekali. ${ }^{8}$

\section{B. HAK ASASI MANUSIA (HAM)}

Istilah hak-hak asasi manusia merupakan terjemahan dari istilah drots de I'homme dalam bahasa Prancis yang berarti "hak manusia", atau dalam bahasa inggrisnya Human Right, yang dalam bahasa belanda disebut menselijke rechten. Kitab suci Al Quran lebih kurang 1400 tahun yang lalu diwahyukan oleh Allah SWT kepada seluruh umat manusia melalui Rasul dan utusannya,Nabi Muhammad SAW mengajarkan dalam firman itu : " tiada paksaan dalam beragama ".

\footnotetext{
${ }^{7}$ Topo santoso, Hukum Pidana Islam (Bandung : asyamil Press dan grafika, 2001) h. 50-51

${ }^{8} \mathrm{Ibid}$, h.15-16

5
} 
Ini merupakan pencerminan nilai-nilai asasi bagi manusia. Hak asasi manusia ( HAM ) menurut UU No . 39 / 1999 adalah seperangkat hak yang melekat pada hakekat manusia seballgai makhluk Tuhan Yang Maha Esa dan merupakan anugrahnya yang wajib dihormati, dijunjung tiknggi dan dilindungi oleh negara, hukum, pemerintah, dan setiap orang demi kehormatan serta perlindungan harkat dan martabat manusia.

Apabila kita memperhatikan di negara kita sendiri, pengakuan dan jaminan perlindungan terhadap hak azasi manusia, ternyata telah cukup banyak diberikan, baik yang ditemukan dalam nilai-nilai yang terkandung dalam Pancasila, Undang-Undang Dasar 1945, serta peraturan perundang-undangan lainnya.

Untuk jelasnya dapat kita rinci sebagai berikut :

1. Pancasila Menurut Franz Magnins-Suseno, "Sebenarnya hak azasi manusia merupakan pengejahwentahan seluruh Pancasila. Masalah hak Azasi manusia dapat dipahami sebagai operasionalisasi Pancasila. “(15-66)

2. Undang-Undang Dasar 1945, sebagian landasan konstitusional.

3. Ketetapan MPR Comer XVII/ MPR / 1998 tentang hak azasi manusia.

4. Undang-Undang Nomer 39 Tahun 1998 tentang Hak Azasi Manusia.

5. Undang-Undang Nomer 26 Tahun 2000 tentang Pengadilan Hak Azasi Manusia .

6. Peraturan perundang-undangan lainnya, antara lain sebagai berikut :
a. Kitab Undang-Undang Hukum Acara Pidana
b. Undang-Undang tentang pemilu
c. Undang-Undang tentang Susunan dan Kedudukan MPR, DPR , DPRD
d. Undang-Undang tentang Kepartaian
e. Undang-Undang tentang Pokok Pers 
Disamping itu, Negara kita telah meratifikasi beberapa konvensi Perserikatan Bangsa-Bangsa tentang Hak Azasi Manusia, antara lain sebagai berikut :

1. International Convention on the Elimination of All Forms Racial Discrimination (1965)

2. International Convention on the Suppression and Punishmentof the Crimeof Apartheid (1973)

3. ILO Convention concerning Equal Remuneration for Men and Women Workes for Work of Equal Value (1951)

4. ILO Convention Concerning Discrimination in Respect of Employment and Accupation (1958)

5. Convention on the Prevention and Punishment of the rime of Genocide (1948)

6. Convention on the Non- Applicability of statutory Lemitation to War Crimes Againts Humanity (1968)

7. Protocol Amending the slavery Convention (1953)

8. Supplementary Convention on the Abolition of Slavery, the Slave Trade, and Instution and Practices Similar to Slavery (1956)

9. Convention For the Suppression of the Traffic on Persons and of the Exploitation of Others (1950)

10. ILO Convention Concerning Forced Laboer (1030)

11. ILO Convention Concerning the Application of the Principles of the Right to Organize (1949)

12. Convention of the Political Right of Women (1952)

13. Convention of the Elimination Alls Forms Discrimination Against Woment (1979)

14. Geneva Convention for the Amelioration of the Condition of the Wounded and Sick in Armed Forces en the Field (1949) 
15. Geneva Convention for the Ameliorationof the Condition of the Wounded and Sick in Shipwreked Members of Armed Forces at Sea (1949)

16. Geneva Convention Relative to the Treatment of Prisoners of War (1949)

17. Geneva Convention Relative to the Protection of Civ lan person in Time of War (194). (13-76)

Pada tahun 1990 telah diratifikasi pula konvensi tentang Hak-Hak anak dengan Keppres Nomor 36 Tahun 1990. tidak sebagaimana lazimnya, konvensi tentang hak-hak anak ini tidak diratifikasi dengan suatu undang-undang, tetapi hanya diretifikasi dengan keppres. Mengingat suatu konvensi yang telah diratifikasi akan berlaku secara umum dan mengikat setiap warga negara, maka ratifikasi setiap konvensi sebaiknya dilakukan dengan suatu undang-undang.

Konvensi-konvensi tersebut diatas diratifikasi sebelum dideklarasikan Rencana Aksi Nasional Hak- hak Azazi Manusia Indonesia 1998-2003, pada 25 juni 1998. Untuk selanjutnya dalam program kegiatan rencana Aksi Nasional Hak- hak Azazi Manusia Indonesia 1998-2003, pada 25 juni 1998, akan diratifikasi secara bertahap beberapa Konvensi Perserikatan Bangsa-Bangsa tentang hak Azazi Manusia, yaitu sebagai berikut :

\section{Tahun I :}

1. Konvensi tentang Hak-hak Ekonomi, Politik, dan Budaya.

2. Konvensi tentang penyiksaan dan perlakuan atau Hukuman lain yang Kejam, Tidak Manusiawai, atau Merendahkan.

3. Konvensi Penghapusan Segala Bentuk Diskriminasi Rasial. Tahun II :

1. Konvensi Pencegahan dan Penghukuman Kejahatan Genocida.

2. Konvensi Perbudakan.

Tahun III : 
Konvensi Perlindungan Hak-hak Semua Pekerja migran dan Anggotaanggota Keluarga.

\section{Tahun IV :}

Konvensi Penghentian Perdagangan Manusia san Ekspoitasi porstitusi. TahunV :

Konvensi Hak - hak Sipil dan Politik (5-8)

Berdasarkan rencana aksi tersebut diatas sampai Sekarang telah diratifikasi lagi beberapa konvensi, yaitu sebagai berikut :

1. Konvensi menentang Penyiksaaan dan Perlakuan atau Hukuman lain yang Kejam, Tidak Manusiawi, atau Merendahkan.

2. Konvensi tentang Hak-hak Ekonomi, Politik, dan Budaya.

3. Konvensi Penghapusan segala Bentuk Diskriminasi Rasia.

Kita Semarang juga telah memiliki Komite Nasional Hak Azasi Manusia ( Komnas Ham), yaitu suatu badan independen yang bertugas memandang pelaksanaan hak azasi manusia di Indonesia. Semua itu bertujuan untuk kemajuan dan perlindungan hak-hak azasi manusia Indonesia. Isu-isu mengenai hak azasi manusia yang menonjol akhir-akhir ini, pada umumnya berkaitan dengan :

1. Hak kebebasan berbicara dan mengeluaarkan pendapat.

2. Hak kebebasan beragama.

3. Hak kebebasan dari rasa takut.

4. Hak kebebasan dari kemelaratan.

Sedangkan kelompok yang paling rawan dalam persoalan pelanggaran hak azasi manusia, antara lain kelompok wanita, kelompok anak-anak dan kelompok buruh. Kelompok-kelompok ini harus mendapat perhatian yang paling besar, dalam upaya perlindungan terhadap hak azasi manusia .

\section{HUKUM PIDANA ISLAM YANG DINILAI KEJAM}


Kritik terhadap hukuman dalam Islam bisa juga disebabkan karena tidak disadarinya alasan spiritual dari hukuman itu. Hukuman bukanlah dijatuhkan secara kejam oleh seseorang pada orang lain. Melainkan suatu pelaksanaan dari ketentuan Allah terhadap hamba-hamba-Nya. Ketaatan kepada hukum Allah adalah karakter dasar bagi masyarakat Muslim yang benar.

Salah satu persoalan yang selalu dibahas oleh para ahli hukum pidana adalah masalah pidana atau hukuman. Sebelum membahas hal-hal diatas kita akan coba melihat bagaimana tuduhan-tuduhan terhadap hukuman dalam system pidana Islam yang kerap kali digambarkan sebagai sesuatu yang kejam, tidak manusiawi, dan barbar. Dalam system ini misalnya dikenal hukuman mati.

Persoalannya sering kali bentuk-bentuk hukuman tersebut hanya dilihat dari satu sisi saja, yaitu kemanusiaan menurut standar abad 20 yang dianggap paling beradab. Tidak dilihat alasan, maksud, tujuan, dan keefektifan hukumanhukuman tersebut. Berkaitan dengan teori pemidanaan ini dikenal adanya beberapa tujuan pemidanaan, yaitu : Retribution (pembalasan), Deterence (pencegahan), dan Reformation (Perbaikan). Banyak penulis menyatakan bahwa satu-satunya tujuan pemidanaan dalam hukum hukum pidana Islam adalah untuk pembalasan semata.

Pada kenyataannya hal tersebut tidak benar. Dalam hukum pidana Islam, hukuman tidak hanya berfungsi sebagai pembalasan, tetapi juga memiliki fungsi pencegahan (umum dan khusus), serta perbaikan. Dalam kenyataannya juga melindungi masyarakat dari tindakan jahat serta pelanggaran hukum (fungsi perlindungan). Hukuman dalam Islam memiliki landasan yang sangat kokoh yaitu Al-Qur'an dan Sunah Nabi SAW, dan bukan berdasarkan dugaan-dugaan manusia semata mengenai hal-hal yang dirasa adil.

Dari sisi kepastian hukum juga jelas karena manusia dilarang mengubah hukuman yang diancamkan, jadi untuk tindak pidana yang diberi ancaman hukuman hadd tidak boleh ada perubahan, perbuatan yang dilarang tetap menjadi 
sesuatu yang diharamkan sampai kapanpun. Bandingkan dengan system hukum di negara-negara Barat yang bahkan untuk perbuatan yang sangat kotor, seperti zinah dapat dilakukan dekriminalisasi. System ini juga mengenal afwan atau pemaafan bagi tindak pidana qishash, seperti pembunuhan atau penganiayaan, jika pihak korban atau keluarga korban mau memaafkan.

System ini juga sangat memperhatikan aspek pencegahan, pendidikan, dan perlindungan bagi masyarakat, serta perbaikan bagi si pelaku. Dikatakan oleh Shiddiqi, hukuman yang ditentukan oleh syari'at hanya dilaksanakan suatu negara Islam. Hukuman ini merupakan bagian dari system Islam dan bila system tersebut mungkin tidak akan tepat sama sekali. Dalam system seperti ini negara melakukan distribusi kekayaan dengan baik, yang bertanggung jawab untuk menolong setiap warga negara, tidak peduli latar belakang suku, ras, bahasa, warna kulit, atau status sosialnya.

Negara juga bertanggung jawab menjamin pekerjaan yang baik bagi warganya, jika pekerjaan itu tidak tersedia atau jika ada seseorang yang tidak mampu bekerja harus diberikan kepadanya harta dari ba'it al mal atau rumah harta negara. Menolong warga negara juga termasuk menghindarkan mereka dari perbuatan terlarang, misalnya dengan melarang sarana-sarana yang mendorong terjadinya berbagai kejahatan.

Maka termasuk didalamnya larangan tempat-tempat prostitusi, larangan minuman keras, larangan menyendiri dengan orang lain yang bukan muhrimnya, larangan tontonan yang membangkitkan nafsu seksual. Sebaliknya dilakukan usaha-usaha mendorong warga negara agar dapat menjalankan ajaran agamanya dengan baik, seperti sholat, puasa, zakat, ibadah haji, dan ibadah-ibadah lain.

\section{PENGGOLONGAN HUKUMAN}


Hukuman dapat dibagi menjadi beberapa golongan. Penggolongan pertama didasarkan atas pertalian satu hukuman dengan hukuman lainnya, dalam hal ini ada empat jenis hukuman :

1. Hukuman Pokok ('uqubah ashliah), misalnya hukuman qishash untuk tindak pidana pembunuhan dan penganiayaan.

2. Hukuman Pengganti ('uqubah badaliah), merupakan pengganti hukuman pokok yang tidak dkumanapat dilaksanakan karena alasan yang sah, seperti hukuman diyat sebagai pengganti hukuman qishash, atau hukuman ta'zir sebagai pengganti hukuman hadd atau qishash yang tidak dilaksanakan. Sebenarnya hukuman diyat itu sendiri adalah hukuman pokok untuk pembunuhan semi sengaja (menyerupai sengaja), demikian pula hukuman ta'zir merupakan hukuman pokok untuk tindak pidana ta'zir.

3. Hukuman Tambahan ('uqubah taba'iah), yaitu hukuman yang mengikuti hukuman pokok tanpa memerlukan keputusan tersendiri seperti larangan menerima warisan bagi pelaku pembunuhan terhadap keluarganya sebagai tambahan hukuman qishash, atau hukuman pencabulan hak sebagai saksi bagi orang yang melakukan tindak pidana qadzaf (memfitnah orang lain berzina).

4. Hukuman Pelengkap ('uqubah takmiliah), yaitu hukuman yang mengikuti hukuman pokok dengan syarat ada keputusan tersendiri dari hakim.

\section{E. PEMBUNUHAN}

Tidak diragukan kembali bahwa tindak kejahatan yang paling menakutkan bagi manusia adalah pembunuhan. Tindakan pembunuhan diancam pidana berat oleh semua system hukum sejak awal sejarah manusia hingga saat ini. Ancaman pidana bagi tindak pidana ini dalam Hukum Pidana Islam dikenal sebagai "Qishash" yaitu pembalasan bagi pelaku seimbang dengan luka yang diderita korban. 
Dalam mengkaji hukum qishash ini, hal yang paling penting adalah klasifikasi pembunuhan itu sendiri: yaitu apakah pembunuhan merupakan bagian dari hukum publik dimana negara harus intervensi ambil bagian dalam penuntututannya, ataukah ia merupakan bagian dari kesalahan perdata atau Tort, dimana pemulihannya dikembalikan kepada orang yang terkena perbuatan itu, apakah ia akan menuntutnya atau tidak.

Tepat yang diberikan oleh Islam bagi kehendak keinginan individu dalam konteks Qishash ini membedakan perlakuan Islam terhadap pembunuhan dari perlakuan system lain. Dimana, dalam hukum Islam pembunuhan terlihat sebagai kesalahan privat, dan pemulihannya menjadi urusan sang korban atau keluarganya. Tetapi penelitian yang lebih jeli akan membawa kesimpulan yang berbeda. Dalam fiqih, tindak pidana pembunuhan ini (Al Qatl) disebut dengan Al Jinayah 'la al Insaniyyah (kejahatan terhadap jiwa manusia), sebutan ini sama dengan pengertian pembunuhan dalam hukum positif.

Dalam KUHP Indonesia sendiri, tindak pidana ini juga dimasukkan dalam bab XIX : kejahatan terhadap nyawa. Dalam hal pembunuhan ini, kami contohkan tentang pembunuhan sengaja. Bahwa suatu pembunuhan baru dapat dikatakan pembunuhan sengaja didalam Islam jika memenuhi unsur-unsur :

1) Yang dibunuh adalah manusia yang diharamkan Allah untuk membunuhnya :

2) Perbuatan itu membawa kematian: dan bertujuan untuk menghilangkan nyawa seseorang.

Para ulama fiqih mengemukakan bahwa ada beberapa bentuk hukuman dikenakan kepada pelaku tindak pidana ini, yaitu :

1) Hukuman Asli, yaitu hukum qishash. Hukuman ini didasarkan pada ketentuan Allah dalam QS. Al Baqarah 178. Artinya : "Hai orang-orang yang beriman, diwajibkan atas kamu qishash berkenaan dengan orang-orang yang dibunuh...." Dalam surat lain QS. Al Maidah (5) ayat 45 : Artinya : "Dan telah kami tetapkan kepada mereka didalamnya (taurat) bahwasannya jiwa (dibalas) 
dengan jiwa...". Dalam hadits Nabi juga ditemui perintah ini : Artinya : "... Siapa yang membunuh dengan sengaja, maka dibalas dengan membunuh (pelaku)nya..." (HR. Abu Dawud dan An Nasai dari Abdullah Bin Abbas). Hukuman qishash tidak dijatuhkan apabila dimaafkan oleh ahli waris. Para ahli waris menurut kesepakatan ahli fiqih, boleh memaafkan terbunuh dengan cara tidak melaksanakan hukuman qishash. Hal ini sesuai dengan firman Allah dalam surat Al Baqarah (2) ayat 178. Artinya : "Maka barang siapa yang mendapatkan suatu pemaafan dari saudaranya, hendaklah (yang memaafkan) mengikuti dengan cara yang baik, dan hendaklah (yang diberi maaf) membayar (Diyat) kepada yang memberi maaf dengan cara yang baik (pula)...” Kemudian dalam surat Al Maidah (5) ayat 46 Allah Swt. berfirman: Artinya : "...dan luka-luka (pun) ada qishashnya, maka melepaskan hak itu (menjadi) penebus dosa baginya..." Sedangkan dalam Sunnah ada riwayat : Artinya : "Sepengetahuan saya setiap ada perkara Qishash dilaporkan kepada Rasulullah Saw, senantiasa dianjurkan untuk dimaafkan ”. (HR. Anas bin Malik). Aturan tentang pemaafan dalam pembunuhan inilah tidak ada dalam hukum positif. Aturan ini juga menepis anggapan bahwa hukuman dalam pidana Islam hanya bertujuan untuk pembalasan semata.

2) Hukuman Pengganti. Menurut ulama fiqih, apabila hukuman qishash gugur (misalnya karena dimaafkan atau karena ada perdamaian), maka ada dua hukuman pengganti lain, yaitu Diyat yang ditanggung sendiri oleh pembunuh, dan hukuman ta'zir.

3) Hukuman Pelengkap. Selain hukuman-hukuman diatas dalam pembunuhan sengaja juga ada hukuman lainnya, yaitu: terhalang hak warisnya, dan terhalang mendapat wasiat dari korban.

\section{F. DUNIA ISLAM MEMILIKI CIRI HAM TERSENDIRI}


Dengan semakin rapatnya hubungan satu negara dengan negara lain di dunia ini, orang-orang diberbagai belahan bumi semakin merasa perlu untuk saling memahami budaya, sistem kehidupan, termasuk hukum dari bangsabangsa lain. Sehingga dibarat orang mempelajari berbagai aspek dari hukum islam, tidak kecuali hukum pidanaya. Pada hakekatnya bahwa negara hukum tidak akan berfungsi sebagaimana mestinya jika tidak ada demokrasi sebaliknya demokrasi tidka akan berfungsi selama HAM terus menerus diperkosa.

Kemunculan kembali negara-negara islam dan negara-negara muslim diantara masyarakat bangsa-bangsa didunia dan ketaatan dari beberapa negara kepada hukum islam sebagai dasar dari sistem hukum mereka menegaskan pentingnya memahami nilai-nilai dan atribut-atribut dari islam dan hukum islam.

Negara muslim yaitu negara dimana mayoritas penduduknya adalah kaum muslimin atau pemerintahnya mewakili mayoritas umat islam. Negara islam merujuk pada suatu bentuk pemerintahan dimana seluruh perlakuan dari seluruh aspek usaha manusia dan hukum menjadi subjek hukum islam, yaitu syariat. Dunia islam mempunyai ciri khas dan keunikan tersendiri. Seperti dunia barat,dunia islam juga memperlihatkan keragaman dan tidak homogen.

Dalam arti, setiap negara dari Aljazair hingga Indonesia mempunyai perbedaan yang amat mendasar, meski mayoritas penduduknya beragama islam. Ternyata komunalitas agama tidak dengan sendirinya berarti komunalitas sosial dan tradisi politik. Sebagaimana masyarakat dan realitas sosialnya berbeda, juga tradisi-tradisinya. Aljazair misalnya, merupakan negara modern yang westernized.

Karena itu, mengalami guncangan hebat saat sebagian warganya menginginkan "negara islam" versi mereka. Sementara itu, negara-negara lain seperti Indonesia, Malaysia dengan mayoritas penduduknya muslim memilih menjadi Negara sekuler, tampaknya perjuangan kelompok-kelompok islam untuk 
membentuk Negara islam tidak berhasil. Kedua negara itu mengambil pemerintahan yang cocok untuk masyarakat pluralitas.

Kendati penduduknya mayoritas muslim, kedua negara itu mempunyai karakter pluralis dan karena itu memilih karakter sekuler. Dan yang sangat menarik, bahwa dari masing-masing negara islam didunia, tidak ada yang mengeluhkan soal penerapan hukum islam karena perbedaan budaya, social ataupun yang lainnya. Tetapi hukum islam bisa berjalan secara seknifikan, walaupun ada perbedaan-perbedaan dari masing-masing negara tersebut.

Hukum islam sangat bersifat fleksibel, artinya tidak kaku seperti halnya yang dibayangkan orang-orang yang kurang dalam memahami hukum islam, karena hukum islam bisa berdiri dimanapun ia berada, walaupun dalam masyarakat yangmemiliki perbedaan budaya, sosial, ekonomi, dan politik. Kita tahu bahwa didalam salah satu kaidah fiqih mengatakan bahwa : "Hukumhukum itu dapat berubah sesuai dengan zaman, tempat, dan keadaan”. Sehingga hakekatnya hukum islam tersebut dapat berubah dalam kondisi dan situasi tertentu. Tetapi hakekatnya tidak berbenturan dengan hukum asal (Al Qur'an dan Hadits).

\section{G. HAM DALAM DUNIA ISLAM}

Berhubung hak asasi manusia merupakan hak-hak dasar yang dibawa manusia semenjak lahir sebagai Anugerah Tuhan Yang Maha Esa, maka perlu dipahami bahwa hak asasi manusia tersebut tidaklah bersumber dari negara dan hukum, tetapi semata-mata bersumber dari Tuhan sebagai pencipta alam semsta beserta isinya, sehingga hak asasi manusia itutidak bisa dikurangi (non derogable right). Oleh karena itu, yang diperlukan dari negara dan hkm adalah suatu pengakuan dan jaminan perlindungan terhadap hak asasi manusia tersebut.

Salah satu kendala bagi perlindungan dan penegakan hak asasi manusia (HAM) dalam masyarakat beragama yang sedang mengalami modernisasi adalah 
keraguan dalam menyikapi hubungan antara agama dan sekulerisme. Hingga kini keduanya dipahami sebagai domain yang berbeda, bahkan berbenturan satu dengan yang lain. Kita tidak boleh lupa, sebagian besar penduduk dunia adalah uma beragama.

Karena itu, keggalan untuk melibatkan prespektif agama sebagai fondasi HAM bukan berarti hanya hilangnya dukungan politik komunitas-komunitas beragama, tetapi juga bisa menjebak mereka melakukan perlawanan terhadap sebagian hak-hak universal itu. Negara-negara muslim sering menjadi sasaran atas pelanggaran-pelanggaran HAM, karena banyak yang menilai bahwa hukum atau undang-undang yang mereka terapkan banyak yang membunuh terhadap hak-hak seseorang.

Seperti pemerintah yang diterapkan oleh Taliban yang ada di Afganistan,misal kaum perempuan tidak boleh keluar rumah dan bersekolah tanpa didampingi muhrimnya. Penerapan ini sangat ditentang oleh banyak negara terutama Eropa. Sehingga kemudian pemerintah Taliban dihantam habis oleh Amerika dengan dalih menghilangkan pemerintah yang dictator, sehingga saat ini pemerintah Taliban sudah tinggal cerita.

Dalam penerapannya ternilai sangat dictator dan kaku(dalam presepsi barat), sehingga dunia barat memberikan pencerminan bahwa hukum islam seakan-akan seperti itu. Padahal jika dikaji secara mendalam, maka akan kita temukan bahwa pengertian penerapan konteks tentang HAM antara tiap-tiap negara pasti memiliki perbedaan yang amat tajam, tak terkecuali pemaknaan antara negara barat dengan timur juga demikian. Sebab masing-masing mempunyai perbedaan kultur yang amat tajam.

Orang timur tengah tidak bisa dipaksakan harus hidup layaknya orang hawai, yang selalu terkenal dengan bikini dan tariannya. Demikian juga orang barat tidak bisa dipaksakan hidup dengan selalu berjubah layaknya orang Arab. Di Negara barat yang dikenal pelopor bahkan sering memaksakan HAM terhadap 
negara-negara lain, bukan berarti bersih dari pelanggaran HAM, bisa kita contohkan seperti Perancis yang baru-baru lalu telah melarang warganya untuk memekai jilbab. Bukankah ini suatu pembunuhan terhadap hak seseorang.

Dan juga bagaimana dengan Amerika yang sampai saat ini juga masih sering memarjinalkan orang-orang kulit hitam dan lain sebagainya. Sehingga suatu kebohongan besar jika suatu negara sudah terbebas dari pelanggaran HAM. Hukum islam sangat menjunjung tinggi terhadap HAM, ini bisa kita pelajari mulai dari hukum pidana, perdata, ataupun yang lainnya. Dan perbedaan dari masing-masing negara dengan penerapan hukum memang disesuaikan dengan faktor kondisi dan situasi negara tersebut.

Islam secara keras melarang total terhadap pembunuhan, pencurian, perampokan, penipuan, pemalsuan, riba, perjudian dan lain-lain. Karena apapun yang diperoleh manusia melalui cara-caraini sebenarnya diperoleh dengan menyebabkan kehilangan dan penderitaan orang lain. Segala macam bisnis yang mengeksploitasi orang lain dan hanya satu pihak saja yang rugi juga dilarang.

Begitu juga dengan monopoli, penimbunan,dan sebagainya: perzinahan dan hubungan seksual yang tidak wajar dilarang keras dalam islam karena semuanya ini tidak hanya merusak moral dan kesehatan dari pelakunya, tetapi juga menyebabkan berbagai penyakit berbahaya (antara lain AIDS), membahayakan kesehatan dan moral bagi masyarakat dan generasi yang akan datang,merusak hubungan manusia satu dengan yang lainnya dan menceraiberaikan susunan dan struktur budaya dan sosial masyarakat.

Islam ingin menghilangkan akar dan cabang kejahatan yang sangat buruk seperti itu. Menarik dicatat dalam kaitan ini, bahwa tidak ada keseragaman penerapan hukum-hukum syariat dinegara-negara muslim.terdapat perbedaan tajam dalam menginterprestasikan hukum-hukum tersebut. 


\section{H. HAK ASASI MANUSIA YANG TERKESAN DIPAKSAKAN}

Sesudah perang dingin arus gelombang hak asasi manusia semakin melanda seantero dunia, malah kadang-kadang negara-negara barat terkesan ingin melaksanakan penerapan konsep hak asasi manusia menurut pandangan mereka terhadap negara-negara lain, tanpa memperhatikan keanekaragaman tata nilai, sejarah, kebudayaan, system, politik, tingkat pertumbuhan sosial dan ekonomi, serta faktor-faktor lain yang dimiliki bangsa yang bersangkutan.

Jadi tidak mungkin konsep hak asasi manusia menurut pandangan barat dipaksakan berlaku bagi negara lain, karena pemaksaan tersebut justru merupakan pelanggaran terhadap Hak Asasi Manusia itu sendiri. Sebagai contoh dapat dikemukakan disini, dua pasal dari Universal Declaration of Human Right, yaitu sebagai berikut :

1. Pasal 16 ayat (1) menyebutkan bahwa seorang laki-laki dan seorang wanita bebas melakukan perkawinan, tanpa dibatasi oleh suku, bangsa, dan agama.

2. Pasal 18 menyebutkan bahwa setiap orang bebas untuk memeluk dan keluar dari suatu agama.

Penerapan kedua pasal ini bagi masyarakat yang beragama Islam tanpa memperhatikan nilai-nilai ajaran Islam yang duanutnya akan bisa menimbulkan masalah, karena menurut keyakinan sebagian umat Islam seorang Muslim dilarang kawin dengan seorang non Muslim, dan perbuatan keluar dari agama Islam adalah murtad dan merupakan dosa besar dan pelakunya halal untuk dibunuh.

Masalah sebenarnya sampai sekarang masih menimbulkan suatu polemik dikalangan umat Islam sendiri.Diantara negara-negara Islam sendiri terdapat perbedaan pendapat dalam menyikapi kedua pasal tersebut diatas, ada yang menolak seperti Saudi Arabia, tetapi mayoritas negara-negara islam menerimanya, seperti Pakistan, Afganistan, dan lain-lain.oleh karena itu yag 
penting bagi kita dalam penerapan hak asasi manusia di suatu Negara, harus memperhatikan sepenuhnya situasi dan kondisi Negara yang bersangkutan.

Isu-isu mengenai hak asasi manusia dewasa ini bukan lagi berkisar masalah pengakuan dan jaminan perlindungan terhadap hak assi manusia, karena hampir di semua negara, baik dalam konstitusinya, maupun dalam peraturan perundang-undangan, telah diberikan pengakuan dan jaminan perlindungan terhadap hak asasi manusia, disamping telh adanya beberapa konvensi perserikatan bangsa-bangsa tentang hak asasi manusia. Masalahnya sekarang tertuju pada isu-isu penegakan hak asasi manusia.

\section{PENUTUP}

1. Dalam hukum islam, mengandung nilai alasan, maksud, tujuan dan keefektifan hukuman-hukuman tersebut. Hukuman bukanlah dijatuhkan secara kejam oleh seseorang pada orang lain tanpa adanya dasar tersebut.

2. Hukum dalam islam memiliki landasan yang sangat kokoh yaitu Al Quran dan Sunnah Nabi SAW. Dan bukan berdasarkan dugaan-dugaan manusia semata mengenai hal-hal yang dirasa adil. Ini menunjukkan kepastian hukum juga jelas dalam hukum islam.

3. Dunia Islam memiliki ciri khas dan keunikan sendiri, masing-masing negara muslim memiliki perbedaan dalam penerapan hukum islm, tetap dengan tujuan yang sama yakni penegakan HAM. Negara Islam merujuk pada suatu bentuk pemerintahan dimana seluruh perlakuan dari seluruh aspek usaha manusia dan hukum menjadi subjek hukum Islam yatu Syari'at.

4. Kegagalan negara-negara dunia islam untuk membnetuk suatu politik demokratis. Ini karena kaum revivalis muslim punya kelemahan dalam komitmen mereka terhadap pluralisme demokrasi. 
Jurnal Keislaman, Vol. 2, No. 1, Maret 


\section{DAFTAR PUSTAKA}

Al quran dan terjemahnya, CV. Diponegoro, Bandung, 2000.

Johny Ibrahim, Hak Asasi Manusia dan Demokrasi, Pascasarjana Program Magister Hukum Universitas Putra Bangsa, 2004.

Jeje Abdul Rojak, Politik Kenegaraan, PT. Bina Ilmu, Surabaya, 1999.

Masjfuk Zuhi, Masail Fiqhiyyah, PT. Toko Gunung Agung, Jakarta, 1997.

Manoveher paydar, Legitimasi Negara Islam, Fajar Pustaka Baru, Yogyakarta, 2003.

Muhammad Ryas Rasyid, Makna Pemerintahan, PT. Yarsif Watampoene, Jakrta, 1997.

Mun'im A. Sirry, Dilema Islam Demokrasi, PT. Gugus Press, Bekasi, 2002.

Ramdlon naming, cita dan citra hak-hak asasi manusia di Indonesia, lembaga kriminologi Universitas Indonesia, Jakarta, 1983.

Rozali Abdullah dan Syamsir, perkembangan HAM dan keberadaan Peradilan HAM di Indonesia, Ghalia Indonesia Jkarta, 2001.

Sulaiman bin Al Ast'ats, Sunan Abi Dawud, Jilid II, Dar Al Fikr, 1994 M/1414

H. Topo santoso, hukum Pidana Islam, Asy Syamil Press dan Grafikka, Bandung, 2001. Undang-undang No. 39 tahun 1999, tentang HAM, sinar grafika, jakarta 2000. 